\title{
EFFECT OF GRADED LEVELS OF GUANIDINE ACETIC ACID IN LOW PROTEIN BROILER DIETS ON PERFORMANCE AND CARCASS PARAMETERS
}

\author{
A.I. El-Faham ${ }^{1}$; A.G. Abdallah ${ }^{2}$; M.H.S. El-Sanhoury1; Nematallah G.M. Ali' ${ }^{1}$; M.A.M.
} Abddelaziz'; A.Y.M. Abdelhady ${ }^{1}$, and A.S.M. Arafa ${ }^{2}$

1. Poultry Production Dept., Fac. of Agric., Ain Shams University, Cairo, Egypt

2. Dept. of Poult. Nut. Res. Anim., Prod. Res. Inst., Agric. Res. Center, Dokki, Giza, Egypt

\section{SUMMARY}

The objective of the work was to investigate the response of broiler chicks to supplementing guanidine acetic acid (GAA) in diets with different protein levels on performance and carcass characteristics. A total number of 360 one day old of male Hubbard broiler chicks were weighted and divided into sex dietary treatments of 60 chicks each with 6 replicates ( 10 chicks each), in $2 \times 3$ factorial design as follows:

$\mathrm{T}_{1}$ standard diets without feed additives $(\mathrm{SD}), \mathrm{T}_{2} \mathrm{SD}\left(\mathrm{T}_{1}\right.$ diets $)+0.06 \%(\mathrm{GAA})$

$\mathrm{T}_{3} \mathrm{SD}\left(\mathrm{T}_{1}\right.$ diets $)+0.12 \%(\mathrm{GAA}), \mathrm{T}_{4}$ Tested diets $(-2 \% \mathrm{CP})$ without feed additives (TD), $\mathrm{T}_{5} \mathrm{TD}\left(\mathrm{T}_{4}\right.$ diets $)+$ $0.06 \%$ (GAA), $\mathrm{T}_{6} \mathrm{TD}\left(\mathrm{T}_{4}\right.$ diets $)+0.12 \%$ (GAA).

The results indicated that:

- Productive performance of broiler chicks including live body weight: Body weight gain, feed conversion ration, performance index, production efficiency factor, protein conversion ratio and energy conversion ratio were significantly affected by feed additives (GAA) and levels of crude protein at experimental period (1-35 days) of age. Feed intake recorded insignificant response due to experimental factors (feed additive or protein level).

- Carcass characteristics: Dietary treatments with different (GAA) levels (0, 0.06 and $0.12 \%$ ) or different protein levels had no significant effect on most studied parameters. It may be concluded that broiler diets containing $2 \%$ crude protein $+1200 \mathrm{~g} \mathrm{GAA} /$ ton or standard diets $+600 \mathrm{~g} \mathrm{GAA} /$ ton would be reason for achievement of maximum performance without adverse effect on carcass parameters.

Keywords: broiler, low protein diets, guanidine acetic acid, performance, carcass characteristics

\section{INTRODUCTION}

Feed cost is the greatest proportion of the total costs in poultry production, representing over than $70 \%$, with most of that cost related to the high price of protein and energy ingredients. Reducing protein and/or energy in broiler diets while linearly decreased body weight gain supplementing these diets with alternative sources that marinating the same performance as recommended levels will result in low cost diets and may improve health and environment of birds (Low et al., 2018; Hai-ming et al., 2015 and Kumar et al., 2016). Considerable research has been conducted on using low-protein diets in poultry. The majority of these published papers reported that feeding broilers low-protein diets supplemented with amino acids gave performance equal to that resulted from conventional protein diets (Bunchasak et al., 1997; Cheng et al., 1997; Azaranik et al., 2010 and Berres et al., 2010). Furthermore, low protein diets are recommended for poultry since high protein diets associated with excessive nitrogen excretion (Corzo et al., 2009). Birds fed low protein diets are forced to utilize the nonessential amino acids efficiently resulted in less nitrogen excretion. As a result, environmental nitrogen pollution related to extensive poultry production is significantly reduced by approximately $24-34 \%$ than that of conventional protein diets (Summer, 1993).

Looking for alternative of feed ingredients or additives that can improve feed utilization and bird's performance is the main task of nutritionists all over the world. One of these additives that has been produced and introduced to Egyptian market recently is Guanidino acetic acid (GAA), commercially known as CreAMINOß, a compound formed from Arg and Gly, and is produced via chemical synthesis from glycine cyanamide. It is transformed in the liver to creatine, a central constituent in energy metabolism, 
resulted in more energy utilization (Dilger et al., 2013). The degradation of creatine results in creatinine, which is excreted in the urine. Therefore, creatine must be continually replaced from dietary sources. Creatine is not found in plant feedstuffs and may be thus deficient in all-vegetable diets. In Egypt and Middle East area vegetable protein diets are predominant in poultry industry. Several research indicated that supplementation of broiler diets with GAA improved weight gain, feed efficiency and increased breast meat yield. Ringel et al. (2008) found significant performance improvements and a higher percentage of breast meat from dietary GAA supplementation $(0.6-1.2 \mathrm{~g} / \mathrm{kg})$. The improvements in bird's performance may be due to the better utilization of energy and protein levels (Lemme et al., 2007a,b 2011; Michiels et al., 2012 and Dilger et al., 2013).

Therefore, the objective of this experiment was to study the impact of supplementing (GAA) in broiler diets with different protein on performance and carcass characteristics of broiler chickens.

\section{MATERIAL AND METHODS}

The present experiment was carried out at the Poultry Production Unit, Faculty of Agriculture, Ain Shams University, Shalaqan, Qalyubia, Egypt.

\section{Experimental design:}

A total of 360, one day old of male, Hubbard broiler chicks were randomly assigned to one of six dietary experimental group (60 chick each) and each treatment had six replicates ( 10 chicks each), in 2 x 3 factorial design. Experiment was conducted from 1 to 35 days of age.

The dietary treatments were as follows:

$\mathrm{T}_{1}$ standard diets without feed additives (SD)

$\mathrm{T}_{2} \mathrm{SD}\left(\mathrm{T}_{1}\right.$ diets $)+0.06 \%$ (GAA)

$\mathrm{T}_{3} \mathrm{SD}\left(\mathrm{T}_{1}\right.$ diets $)+0.12 \%$ (GAA)

$\mathrm{T}_{4}$ Tested diets (-2\% CP) without feed additives (TD)

$\mathrm{T}_{5} \mathrm{TD}\left(\mathrm{T}_{4}\right.$ diets $)+0.06 \%$ (GAA)

$\mathrm{T}_{6} \mathrm{TD}\left(\mathrm{T}_{4} \operatorname{diets}\right)+0.12 \%(\mathrm{GAA})$

Standard diets (SD), represent all requirements of birds according to standards requirements guide and calculated analysis of the experimental diets were done according to (NRC, 1994). The standard and test diets are shown in Table (1)

- $\quad$ GAA, CreAmino, contain 94\% guianido acetic acid and purchased from Evonik Industries.

- The experimental diets based on yellow corn, soybean meal and corn gluten meal were formulated to obtain starter (1-14 days), grower (15-28 days) and finisher (29-35 days) diets.

Experimental diets were provided as mash feed in (metallic feeders) and water (automatic nipples) were provided for adlibitum consumption

\section{Measurements:}

\section{Productive performance}

The performance parameters included live body weight and feed intake which were determined during experimental periods and then body weight gain, feed conversion ratio ( $\mathrm{g}$ feed/g gain), performance index according to North (1981), production efficiency factor according to Emmert (2000), protein conversion ratio and energy conversion ratio were calculated corresponding during experimental period (1-35) days of age.

\section{Carcass characteristics}

At the end of experiment ( 35 days of age) four chickens of each dietary treatments were randomly taken and slaughtered to determine the percentages of carcass total edible parts (carcass + liver + gizzard + heart) and abdominal fat percentage.

\section{Statistical analysis}

Data obtained was analyzed using the general linear models procedure of SAS software (SAS Institute, 
2001). When differences among means were found, means were separated using Duncan's (Duncan's 1955) multiple ranges test at $(\mathrm{P}<0.05)$.

The statistical model was:

$$
\mathrm{Y}_{\mathrm{ijk}}=\mu+\mathrm{D}_{\mathrm{i}}+\mathrm{E}_{\mathrm{j}}+\mathrm{D} * \mathrm{E}_{\mathrm{ij}}+\mathrm{e}_{\mathrm{ijk}}
$$

Where: $\mathrm{Y}_{\mathrm{ijk}} \quad=$ the effect of the observation, $\mu \quad=$ The overall mean, $\mathrm{D}_{\mathrm{i}} \quad=$ The effect of the diets, $\mathrm{e}_{\mathrm{j}} \quad=$ The effect of the feed additives, $\mathrm{D} * \mathrm{E}_{\mathrm{ij}} \quad=$ The interaction between diets and feed additives, $\mathrm{e}_{\mathrm{ijk}} \quad=$ The experimental error

Table (1): Composition and calculated chemical analyses of experimental diets .

\begin{tabular}{lcccccc}
\hline \multirow{2}{*}{ Ingredient \% } & \multicolumn{3}{c}{ Standard diet* } & \multicolumn{3}{c}{$-2 \%(\mathrm{CP})$ diet ** } \\
\cline { 2 - 7 } & Starter & Grower & Finisher & Starter & Grower & Finisher \\
\hline Yellow corn & 51.55 & 57.23 & 62.59 & 56.91 & 62.61 & 67.92 \\
Soybean meal $(44 \%)$ & 35 & 29.79 & 24.70 & 30.20 & 24.96 & 19.90 \\
Corn gluten meal (62\%) & 5.20 & 4.90 & 4.60 & 4.70 & 4.40 & 4.10 \\
Soy oil & 3.5 & 4.00 & 4.25 & 3.00 & 3.50 & 3.75 \\
Limestone & 1.35 & 1.10 & 1.08 & 1.35 & 1.12 & 1.10 \\
Di-calcium phosphate & 1.90 & 1.68 & 1.55 & 1.95 & 1.71 & 1.60 \\
Premix*** & 0.30 & 0.30 & 0.30 & 0.30 & 0.30 & 0.30 \\
Salt (NaCl) & 0.40 & 0.40 & 0.40 & 0.40 & 0.40 & 0.40 \\
Dl-Methionine & 0.31 & 0.24 & 0.21 & 0.37 & 0.30 & 0.26 \\
Lysine HCl & 0.32 & 0.25 & 0.23 & 0.44 & 0.38 & 0.35 \\
L-Arginine & 0.07 & 0.05 & 0.04 & 0.21 & 0.18 & 0.19 \\
L-Threonine & 0.10 & 0.06 & 0.05 & 0.17 & 0.14 & 0.13 \\
Total & 100 & 100 & 100 & 100 & 100 & 100 \\
\hline Calculated analysis **** & & & & & & 3235 \\
\hline ME (kcal/ kg) & 3040 & 3151 & 3230 & 3045 & 3157 & 17.07 \\
CP\% & 23.01 & 21.01 & 19.04 & 21 & 19.03 & 190 \\
Calorie / protein ratio (C/P) & 132 & 150 & 170 & 145 & 166 & 0.85 \\
Calcium \% & 1.05 & 0.90 & 0.85 & 1.05 & 0.90 & 0.42 \\
Available Phosphorous \% & 0.50 & 0.45 & 0.42 & 0.50 & 0.45 & 0.56 \\
Methionine \% & 0.69 & 0.60 & 0.54 & 0.73 & 0.63 & 0.86 \\
Methionine + cysteine \% & 1.08 & 0.99 & 0.91 & 1.08 & 0.96 & 1.16 \\
Lysine & 1.44 & 1.29 & 1.16 & 1.44 & 1.29 & 1.15 \\
Arginine & 1.46 & 1.29 & 1.14 & 1.46 & 1.28 & 0.75 \\
Threonine & 0.95 & 0.84 & 0.75 & 0.95 & 0.84 & 0.20 \\
Tryptophan & 0.31 & 0.27 & 0.24 & 0.27 & 0.24 &
\end{tabular}

* Standard diets: represent all requirements of birds according to standards requirement guide.

** $-2 \%(C P)$ diets: represent all requirements of birds according to meet or exceed diets were formulated standard requirements of Hubbard guide, except for crude protein which was reduced by about $2 \%$ of (starter, grower or finisher) diets.

*** Composition of each $3 \mathrm{~kg}$ of vitamin and minerals premix contain: 15000000 I.U VIT. A, 5000000IU Vit. D3, 50000 mg. VIT. E, $3000 \mathrm{mg}$. VIT. K3, $3000 \mathrm{mg}$. VIT. B1, $8000 \mathrm{mg}$. VIT. B2, $4000 \mathrm{mg}$. VIT. B6, 20 mg. VIT. B12, $15000 \mathrm{mg}$. Pantothenic acid, $60000 \mathrm{mg}$. Niacin, $1500 \mathrm{mg}$. Folic acid, $200 \mathrm{mg}$. Biotin, $200000 \mathrm{mg}$ VIT C, 700 gm. Choline chloride, $80 \mathrm{gm}$. Mn, $80 \mathrm{gm}$. Zn, $60 \mathrm{gm}$. Iron, $10 \mathrm{gm}$. Cu, $1 \mathrm{gm}$. Iodine, and $0.2 \mathrm{gm}$. Selenium, where CaCo3 was taken as a carrier up to $3 \mathrm{~kg}$, the inclusion rate was $3 \mathrm{~kg}$ premix / Ton feed

**** Calculated analyses of the experimental diets were done according to $(N R C, 1994)$.

\section{RESULTS AND DISCUSSION}

\section{Effect of dietary treatments on productive performance}

The effect of feeding different protein diets with or without (GAA) on productive performance of broiler chicks can be shown as follows: 


\section{Live body weight (LBW) and body weight gain (BWG)}

It is worth to note that broiler chicks fed low protein diets (-2\% CP) during experimental period (35 days of age) reflected the lowest significant (LBW and BWG) compared with those fed standard diets and the corresponding values for (LBW) were (2006.39 g versus $2063.33 \mathrm{~g}$ ), respectively and BWG showed similar trend (1996.00 versus $2024.33 \mathrm{~g})$, respectively.

The explanation of that could be related to the fact that standard diets were formulated to meet the optimum nutrient requirements for broiler chicks based on the recommendations of NRC (1994). However, industry standards diverge from NRC (1994) recommendations particularly because lower CP diets are found to be more economical by least-cost linear feed formulation models. The current results are in agreement with those reported by Sterling et al. (2003); Rezaei et al., (2004); Aftab et al., 2006; Waguespack et al., 2009), Berres et al. (2010). They concluded that BWG increased, as dietary crude protein increased. On the other hand, Kamran et al. (2004) concluded that dietary protein level of broiler could be reduced from $23 \%$ to $20 \%$, with beneficial effects on growth performance and increased economic returns

Bregendahl et al., (2002) suggested that the insufficiency of low-CP diets to restore performance level to that of standard CP diets cannot be attributed to the lack of essential AAS alone and differences in the level of CP, AA fortification, ingredients used, birds, age as well as strain may have contributed to some of the variation in reported performance.

Data presented in (Table 2) indicates that during experimental period (0-35 days) of the study chicks fed (GAA: 0.06 and $0.12 \%$ ) reflected the highest significant results in both LBW and BWG compared with unsupplemented diets $(0.0 \%$ GAA). At the end of the experimental period, chicks fed diets supplemented with GAA supported the highest LBW (1977.08, 2070.42 and $2057.08 \mathrm{~g}$ ) respectively and the differences were significant compared with those fed $(0.0 \%$ GAA). In addition, feeding broiler chicks diets

Table (2) Effect of different dietary treatments on productive performance

\begin{tabular}{|c|c|c|c|c|c|c|c|c|c|}
\hline \multirow{2}{*}{ Item } & \multirow{2}{*}{$\begin{array}{c}\text { Crude protein } \\
(\mathrm{CP})\end{array}$} & \multicolumn{3}{|c|}{$\mathrm{GAA} * \%$} & \multirow[t]{2}{*}{ Overall } & \multicolumn{4}{|c|}{ Significant } \\
\hline & & 0.00 & 0.06 & 0.12 & & MSE & \multirow[t]{2}{*}{$\mathrm{CP}$} & GAA & $\mathrm{CP} * \mathrm{GAA}$ \\
\hline \multicolumn{9}{|c|}{ Live body weight (g) } & \\
\hline & Standard diets** & 1996.67 & 2114.17 & 2079.17 & $2063.33^{\mathrm{a}}$ & & & & \\
\hline \multirow{2}{*}{ At 5 weeks } & $-2 \%(\mathrm{CP})$ diets $* * *$ & 1957.50 & 2026.67 & 2035.00 & \multirow[t]{2}{*}{$2006.39^{b}$} & 62.14 & $*$ & $* *$ & NS \\
\hline & overall & $1977.08^{b}$ & $2070.42^{\mathrm{a}}$ & $2057.08^{\mathrm{a}}$ & & & & & \\
\hline \multicolumn{10}{|c|}{ Body weight gain (g) } \\
\hline \multirow{3}{*}{ 0-5 weeks } & Standard diets** & \multirow{2}{*}{$\begin{array}{l}1957.67 \\
1918.50\end{array}$} & \multirow{2}{*}{$\begin{array}{l}2075.17 \\
1987.67\end{array}$} & 2040.17 & \multirow{2}{*}{$\begin{array}{l}2024.33^{\mathrm{a}} \\
1967.39^{\mathrm{b}}\end{array}$} & & & & \\
\hline & $-2 \%(\mathrm{CP}) \operatorname{diets} * * *$ & & & 1996.00 & & 62.14 & * & $* *$ & NS \\
\hline & overall & $1938.08^{b}$ & $2031.42^{\mathrm{a}}$ & $2018.08^{\mathrm{a}}$ & & & & & \\
\hline \multicolumn{10}{|c|}{ Feed intake $(\mathrm{g})$} \\
\hline & Standard diets** & 3203.17 & 3326.67 & 3272.83 & 3267.56 & & & & \\
\hline \multirow[t]{2}{*}{$0-5$ weeks } & $-2 \%(\mathrm{CP})$ diets $* * *$ & 3385.00 & 3270.33 & 3244.17 & 3299.83 & 115.09 & NS & NS & * \\
\hline & overall & 3294.08 & 3298.50 & 3258.50 & & & & & \\
\hline \multicolumn{10}{|c|}{ Feed conversion ratio (g feed/g gain) } \\
\hline \multirow{3}{*}{$0-5$ weeks } & Standard diets** & 1.64 & 1.60 & 1.60 & $1.62^{\mathrm{b}}$ & & & & \\
\hline & $-2 \%(\mathrm{CP}) \operatorname{diets}^{* * *}$ & 1.77 & 1.65 & 1.63 & $1.68^{\mathrm{a}}$ & 0.01 & $* *$ & $* *$ & $* *$ \\
\hline & overall & $1.70^{\mathrm{a}}$ & $1.62^{\mathrm{b}}$ & $1.62^{\mathrm{b}}$ & & & & & \\
\hline
\end{tabular}

* GAA: Guanidino acetic acid.

** Standard diets: represent all requirements of birds according to standards requirement guide.

*** -2\% CP diets: represent all requirements of birds according to standards requirement guide, except for crude protein which was reduced by about $2 \%$ of (starter, grower or finisher) diets.

$a, b:$ Means in the same row or column with the same letters are not significantly different. MSE: Mean standard error NS: Non-significant, *: $(P \leq 0.05) * *:(P \leq 0.01)$ 
supplemented with $600 \mathrm{~g} / \mathrm{ton}$ or $1200 \mathrm{~g} / \mathrm{ton}$ GAA showed an increased in BWG by 4.60 and $3.96 \%$ compared with those fed $0.0 \%$ GAA diets. These results are in agreement with those reported by many investigators (Lemme et al., (2007 and 2010); (Brosnan et al., 2009); Michiels et al. (2012) and Ringel et al. (2008 a, b).

They concluded that GAA supplementation of up to $0.12 \%$ to all-vegetable diets has been shon to improve performance in broiler chicks, turkey as well as broiler breeders. On the same order, Michiels et al. (2012) concluded that, the effect of GAA supplementation to broiler diets on body weights or weight gains was small and except for the finishing period, the differences as compared to the control group were not significant.

Therefore, the mechanism by with GAA affects broiler performance is not fully understood. GAA is a natural precursor of creatine, which is involved in cell energy metabolism, particularly in tissues with high and varying energy demand such as skeletal muscle (Michiels et al., 2012). In fast-growing animals fed allvegetable diets lacking creatine, GAA may restore creatine reserves, thus improving tissue energy metabolism and body growth. Another mode of action of GAA may be associated with amino acid metabolism and GAA supplementation may spare arginine, one of the potentially limiting amino acids in low-protein broiler diets (Baker, 2009).

Indeed, Dilger et al., (2013) showed that GAA supplementation markedly improved growth of chickens fed arginine-deficient casein based diets. In practical type diets with moderate arginine deficiency, there was no growth response to GAA.

\section{Feed intake (FI) and feed conversion ratio (FCR)}

The effect of the studied factors on (FI) and (FCR) are presented in Table (2) showed that no significant differences were observed for (FI) within different experimental groups in overall periods (1-35 days). Chicks fed low protein diets $(-2 \% \mathrm{CP})$ consumed more feed $(3299.83 \mathrm{~g})$ act as $101.0 \%$ in (overall period) more than chicks that fed standard diets being $(3267.56 \mathrm{~g})$ respectively. Moreover, no significant differences were found in feed intake between chicks fed GAA $(0,0.06$ and $0.12 \%)$ diets during the studied period (1-35 days) of age and the corresponding values ranged between (3258.5 and $3298.5 \mathrm{~g}$ ) and broiler chicks fed $(0.06 \%$ GAA) diets gave the highest values while, chicks fed $(0.12 \%$ GAA) diets had the lowest values and differences among treatments were insignificant.

Results presented in Table (2) showed significant differences in feed conversion ratio between broiler chicks fed standard diets and low CP (-2\%) diets in whole period (1.62 vs- 1.68).

On the other hand, the best FCR during whole experimental period was detected for the chicks fed diets supplemented with GAA (1.62 for both 0.06 or $0.12 \%$ ). On the other hand, the worst FCR were found in chicks fed $(0.0 \%$, GAA, 1.70) diets, which could be due to the lowest live weight gain and higher feed intake.

These results were reported by the finding of Hidalgo et al. (2004) who found that birds provided low CP and low ME diets had increased feed consumption, but this increase could not compensate for the reduced growth and did not allow for complete recovery of final LBW. These results are in harmony with those obtained by Malheiros et al. (2003) they observed that chickens fed low crude protein diet showed a reduced body weight, feed intake and FCR compared to those fed low lipid and low carbohydrate diets.

On the other hand, GAA supplementation $(0.06 \%)$ to Cobb 500 broiler diets significant improved FCR from 23 to 40 day (finisher period) and 0 to 40 day of age (whole experimental period) and reduced feed intake from 23 to 40 day of age $(\mathrm{P} \leq 0.09)$, with no significant effects on BWG (Mousavi et al. 2012).

Similar observation were reported by Abudabos et al. (2014) found that supplementation of broiler diets with $0.06 \%$ GAA resulted in a significant $(\mathrm{P}<0.05)$ decrease in voluntary feed intake and significantly $(\mathrm{P}<0.001)$ improved feed conversion ratio.

\section{Protein conversion ratio (PCR) and energy conversion ratio (ECR)}

As shown in Table (3) it was revealed from obtained data that values of the PCR showed differences significant during whole experiment period $(0-5$ weeks) were significant $(\mathrm{P}<0.01)$, the low protein diets $(-$ $2 \% \mathrm{CP}$ ) were used in this trail, improved PCR in cumulative period (0.32 vs, 0.34$)$ compared with chicks fed standard diets. 
On the other hand, addition of GAA affected on PCR period whereas chicks fed GAA (0.06 or $0.12 \%)$ had better PCR values than chicks fed $(0.0 \%$ GAA) being $(0.32 \mathrm{VS}, 0.34)$ in whole experimental period.

Table (3): Effect of different dietary treatment on Protein Conversion Ratio (PCR) and Energy Conversion Ratio (ECR) of broiler chickens

\begin{tabular}{cccccccccc}
\hline \multirow{2}{*}{ Item } & \multirow{2}{*}{ Crude protein (CP) } & \multicolumn{3}{c}{ GAA *\% } & Overall & \multicolumn{2}{c}{ Significant } \\
\cline { 3 - 9 } & 0.00 & 0.06 & 0.12 & & MSE & CP & GAA & CP*GAA \\
\hline Protein Conversion Ratio (PCR) & & & & & & & & \\
& Standard diets** & 0.34 & 0.34 & 0.34 & $0.34^{\mathrm{a}}$ & & & & \\
$0-5$ weeks & $-2 \%(\mathrm{CP})$ diets*** & 0.33 & 0.31 & 0.31 & $0.32^{\mathrm{b}}$ & 0.01 & $* *$ & $* *$ & $* *$ \\
& overall & $0.34^{\mathrm{a}}$ & $0.32^{\mathrm{b}}$ & $0.32^{\mathrm{b}}$ & & & & & \\
Energy Conversion Ratio (ECR) & & & & & & & & \\
$\quad$ Standard diets** & 5.20 & 5.15 & 5.13 & $5.16^{\mathrm{b}}$ & & & & \\
$0-5$ weeks & $-2 \%(\mathrm{CP})$ diets*** & 5.60 & 5.24 & 5.21 & $5.35^{\mathrm{a}}$ & 0.09 & $* *$ & $* *$ & $* *$ \\
& overall & $5.40^{\mathrm{a}}$ & $5.20^{\mathrm{b}}$ & $5.17^{\mathrm{b}}$ & & & & & \\
\hline
\end{tabular}

* GAA: Guanidino acetic acid.

** Standard diets: represent all requirements of birds according to standards requirement guide.

*** $-2 \%$ CP diets: represent all requirements of birds according to standards requirement guide, except for crude protein which was reduced by about $2 \%$ of (starter, grower or finisher) diets.

$a, b:$ Means in the same row or column with the same letters are not significantly different. MSE: Mean standard error NS: Non-significant, *: $(P \leq 0.05)$ **: $(P \leq 0.01)$

Values of ECR in Table (3) showed that significant differences were observed within different experimental groups in whole experimental periods. Chicks fed standard diets gave better values compared with those fed $(-2 \% \mathrm{CP})$ in whole (5.16 vs, 5.35$)$ experimental period.

In addition, significant difference were observed between, chicks fed $(0.0 \%$ GAA $)$ and $(0.06$ or $0.12 \%$, GAA) in all experimental period (1-35 days of age) and the best (ECR) was recorded with chicks fed $(0.12 \%$ GAA, 5.17) diets compared with those fed (0.06\% GAA, 5.20) diets, while those fed on (0.00\% GAA, 5.40) diets were the worst during whole experimental periods. This in line with the on findings of Mousavie et al. (2013) who reported that supplementation with $(0.06 \%$ GAA) was effective in reducing the caloric consumption per kilogram of (BWG) and per kilogram of carcass weight only at 100 and $95 \%$ of energy recommendations. Overall, dietary supplementation of GAA improved FCR and energy efficiency.

\section{Performance index (PI) and production efficiency factor (PEF)}

The results in Table (4) showed the relationship between different treatment (dietary protein levels and GAA supplementation levels) and PI or PEF. The response showed significant differences in PI and PEF during experimental period (1-35 days of age). Moreover, PI and PEF values were significant decreased by decreasing $\mathrm{CP}$ levels in diets during experimental period.

\section{Table (4): Effect of different dietary treatment on performance index (PI) and production efficiency factor (PEF) of broiler chickens}

\begin{tabular}{|c|c|c|c|c|c|c|c|c|c|}
\hline \multirow{2}{*}{ Item } & \multirow{2}{*}{$\begin{array}{c}\text { Crude } \\
\text { protein }(\mathrm{CP})\end{array}$} & \multicolumn{3}{|c|}{ GAA\% } & \multirow{2}{*}{ Overall } & \multicolumn{4}{|c|}{ Significant } \\
\hline & & 0.00 & 0.06 & 0.12 & & MSE & $\mathrm{CP}$ & GAA & $\mathrm{CP} * \mathrm{GAA}$ \\
\hline \multirow{2}{*}{ 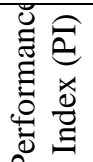 } & \multirow{2}{*}{$\begin{array}{l}\text { Standard } \\
\text { diets** } \\
-2 \%(\mathrm{CP}) \\
\text { diets*** }\end{array}$} & 122.05 & 131.90 & 129.62 & $127.85^{\mathrm{a}}$ & \multirow[b]{2}{*}{3.60} & \multirow[b]{2}{*}{$* *$} & \multirow[b]{2}{*}{$* *$} & \multirow[b]{2}{*}{ NS } \\
\hline & & 110.98 & 123.19 & 125.21 & $119.79^{b}$ & & & & \\
\hline
\end{tabular}


Egyptian J. Nutrition and Feeds (2019)

\begin{tabular}{|c|c|c|c|c|c|c|c|c|c|}
\hline \multirow{4}{*}{ 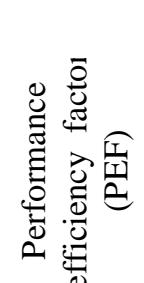 } & overall & $116.51^{\mathrm{b}}$ & $127.54^{\mathrm{a}}$ & $127.42^{\mathrm{a}}$ & \multirow[b]{2}{*}{$365.30^{\mathrm{a}}$} & \multirow{4}{*}{10.30} & \multirow{4}{*}{$* *$} & \multirow{4}{*}{$* *$} & \multirow{4}{*}{ NS } \\
\hline & $\begin{array}{l}\text { Standard } \\
\text { diets** }\end{array}$ & 348.71 & 376.84 & 370.35 & & & & & \\
\hline & $\begin{array}{l}-2 \%(\mathrm{CP}) \\
\text { diets*** }\end{array}$ & 317.08 & 351.98 & 357.76 & $342.27^{\mathrm{b}}$ & & & & \\
\hline & overall & $332.90^{\mathrm{b}}$ & $364.41^{\mathrm{a}}$ & $364.05^{\mathrm{a}}$ & & & & & \\
\hline
\end{tabular}

* GAA: Guanidino acetic acid.

** Standard diets: represent all requirements of birds according to standards requirement guide.

*** -2\% CP diets: represent all requirements of birds according to standards requirement guide, except for crude protein which was reduced by about $2 \%$ of (starter, grower or finisher) diets.

$a, b$ : Means in the same row or column with the same letters are not significantly different. MSE: Mean standard error NS: Non-significant, *: $(P \leq 0.05) * *:(P \leq 0.01)$

Broiler chicks fed low protein level $(-2 \% \mathrm{CP})$ gave the lowest figures (119.79 and 342.27) respectively while, chicks fed standard diets had the highest figures (127.85 and 365.30) respectively and differences among treatments were significant. Previously mentioned results agree with those observed by Abd El-Hady (2012) who stated that performance index effect by dietary energy and protein whereas chicks fed normal crude protein $(\mathrm{NCP})$ were highest than medium crude protein (MCP) and low crude protein (LCP) by (116.00, 107.33 and 87.03, respectively).

Also, Rezaei et al. (2004) found that reducing dietary protein in broiler diets decreased weight gain, decreased feed consumption, but it had no significant effect on feed conversion ratio in all phases of the experiment. In the same order, GAA $(0.06 \%)$ supplementation to broiler diets reflected the highest figures for (PI 127.54 or PEF, 364.41) compared with chicks fed unsuplemented diets (0.0\%, GAA) and the corresponding figures being (116.51 or 332.90) respectively and differences between treatments were significant.

These results are in agreement with several reports demonstrating that positive impact on birds performance, PI and PEF of supplementing the diets with GAA (Michiels et al., 2012) and GAA + amino acids (Arafa et al., 2017)

\section{Effect of different dietary treatments on carcass characteristics}

Table (5) were summarized carcass characteristics (\%) at (5 weeks) old of broiler chickens received different dietary treatments (protein and GAA levels).

As shown in Table (5) no significant differences were observed in percentages of carcass, giblets, total edible parts and abdominal fat between all treatments. Numerically, the chickens fed standard diets had the highest percentages which recorded values $(67.37,5.34,72.72$ and 1.02 , respectively) compared with chickens fed $-2 \%$ (CP) diets being $(67.08,4.37,71.45$ and $0.98 \%$ respectively). The differences among treatments were not significant.

On the other hand, experimental treatments with different GAA levels (0.0, 0.06 and $0.12 \%)$ had no significant effect on most studied parameters. The corresponding values for carcass $\%$ ranged between 66.94 and 67.39, giblets \% ranged between 4.37 and 5.79, total edible parts \% ranged between 71.71 and 72.73 , while abdominal fat $\%$ ranged between 0.96 and 1.05. Numerically chickens fed diets supplemented with $0.12 \%$ GAA had the lowest percentages on most studied parameters, except abdominal fat $\%$ and the differences failed to be significant compared with those fed other experimental diets.

These results agreed with those reported by many investigators (Kamran et al. (2008a), Berres et al. (2010), Laudadio et al. (2012), Mousavi et al. (2013) and Abudabos et al. (2014) who all reported that dietary protein levels or GAA with or without amino acids had no significant effects in carcass weight, dressing percentage and abdominal fat, while results disagreed with those of (Kidd et al. (1996), Nagwaz et al. (2006), Kumar et al. (2016) and Law et al. 2018) who reported that reducing dietary crude protein linearly decreased the carcass yield percentage, breast meat and conversely increased the abdominal fat, while results disagreed with those of Esser et al. (2017) and Ahmadispour et al. (2018) who reported that carcass yield percentages was significant increased by the dietary inclusion of the GAA compared with the control group. 
Table (5): Effect of different dietary treatment on carcass characteristics (\%) of broiler chickens

\begin{tabular}{|c|c|c|c|c|c|c|c|c|c|}
\hline \multirow{2}{*}{ Item } & \multirow{2}{*}{ Crude protein $(\mathrm{CP})$} & \multicolumn{3}{|c|}{$\mathrm{GAA} * \%$} & \multirow{2}{*}{ Overall } & \multicolumn{4}{|c|}{ Significant } \\
\hline & & 0.00 & 0.06 & 0.12 & & MSE & $\mathrm{CP}$ & GAA & $\overline{\mathrm{CP} * \mathrm{GAA}}$ \\
\hline \multirow{4}{*}{ Carcass } & Standard diets** & 66.61 & 66.71 & 68.78 & 67.37 & & & & \\
\hline & $-2 \%(\mathrm{CP})$ diets $* * *$ & 68.17 & 67.17 & 65.89 & 67.08 & 2.16 & NS & NS & NS \\
\hline & overall & 67.39 & 66.94 & 67.34 & & & & & \\
\hline & Standard diets** & 2.19 & 2.24 & 2.16 & 2.20 & & & & \\
\hline \multirow[t]{3}{*}{ Liver } & $-2 \%(\mathrm{CP})$ diets $* * *$ & 1.99 & 2.20 & 2.06 & 2.08 & 0.28 & NS & NS & NS \\
\hline & overall & 2.09 & 2.22 & 2.11 & & & & & \\
\hline & Standard diets** & 1.64 & 3.78 & 2.00 & 2.47 & & & & \\
\hline \multirow[t]{3}{*}{ Gizzard } & $-2 \%(\mathrm{CP})$ diets $* * *$ & 1.97 & 1.80 & 1.60 & 1.79 & 1.41 & NS & NS & NS \\
\hline & overall & 1.80 & 2.79 & 1.80 & & & & & \\
\hline & Standard diets** & 0.47 & 1.07 & 0.48 & 0.67 & & & & \\
\hline \multirow{3}{*}{ Heart } & $-2 \%(\mathrm{CP})$ diets $* * *$ & 0.56 & 0.49 & 0.44 & 0.50 & 0.41 & NS & NS & NS \\
\hline & overall & 0.52 & 0.78 & 0.46 & & & & & \\
\hline & Standard diets** & 4.30 & 7.09 & 4.64 & 5.34 & & & & \\
\hline \multirow[t]{2}{*}{ Giblets } & $-2 \%(\mathrm{CP})$ diets $* * *$ & 4.52 & 4.49 & 4.10 & 4.37 & 1.84 & NS & NS & NS \\
\hline & overall & 4.41 & 5.79 & 4.37 & & & & & \\
\hline \multirow{4}{*}{$\begin{array}{l}\text { Total edible } \\
\text { parts***** }\end{array}$} & Standard diets** & 70.92 & 73.80 & 73.43 & 72.72 & & & & \\
\hline & $-2 \%(\mathrm{CP})$ diets $* * *$ & 72.69 & 71.66 & 69.99 & 71.45 & 2.71 & NS & NS & NS \\
\hline & overall & 71.81 & 72.73 & 71.71 & & & & & \\
\hline & Standard diets** & 1.20 & 0.96 & 0.92 & 1.02 & & & & \\
\hline \multirow[t]{2}{*}{ Abdominal fat } & $-2 \%(\mathrm{CP})$ diets $* * *$ & 0.79 & 0.96 & 1.19 & 0.98 & 0.43 & NS & NS & NS \\
\hline & overall & 1.00 & 0.96 & 1.05 & & & & & \\
\hline
\end{tabular}

* GAA: Guanidino acetic acid.

** Standard diets: represent all requirements of birds according to standards requirement guide.

*** $-2 \%$ CP diets: represent all requirements of birds according to standards requirement guide, except for crude protein

which was reduced by about $2 \%$ of (starter, grower or finisher) diets.

**** Total edible parts (carcass weight + giblets weight)

$a, b:$ Means in the same row or column with the same letters are not significantly different. MSE: Mean standard error NS: Non-significant, *: $(P \leq 0.05) * *:(P \leq 0.01)$

\section{CONCLUSION}

This was clearly demonstrated in this study, the best performance was seen when 0.06 $\%$ or $0.12 \%$ guanidine acetic acid incorporated in the standard or $-2 \mathrm{CP}$ broiler diets.

\section{REFERENCES}

Abd El-Hady, A.Y. (2012). Effect of enzyme preparation on apparent metabolizable energy of broiler diets. M.Sc. Thesis, Faculty of Agric., Ain Shams Univ., Egypt.

Abudabos A. M., F. Saleh, A. Lemme and Hana A. Zakaria (2014).The relationship between guanidino acetic acid and metabolisable energy level of diets on performance of broiler chickens. Ital. J. of Anim. Sci. 13: 548-556.

Aftab U, M. Ashraf, Z. Jiang (2006). Low protein diets for broilers. Worlds Poult Sci J. 62:688-701. 
Ahmadipour B., F. Khajali and M. R. Sharifi (2018). Effect of guanidinoacetic acid supplementation on growth performance and gut morphology in broiler chickens. Poult. Sci. J. 2018, 6: 19-24.

Arafa, A.S.M.; A.I. El-Faham; A.G. Abdallah and M.H.S.; El-Sanhoury (2017). Effect of guanidine acetic acid with or without amino acids and feed enzyme on performance, carcass characteristics and economic efficiency in broilers fed corn/soy based diets. Egyptian J. Nut. And Feeds. 20(2), 93-102.

Azarnik A., M. Bokarpour, M. Eslami, M. R. Ghorbani and K. Mirzadeh (2010). The effect of different levels of diet protein on broiler performance in ad libitum and feed restriction method. J. of Anim. and Vet. Advances, 9: 631-634.

Baker D. H., (2009). Advances in protein-amino acid nutrition of poultry. Amino Acids 37: 29-41.

Berres J., S. L. Vieira, M. T. Kidd, D. Taschetto, D. M. Freitas, R. Barros and E. T. Nogueira (2010). Supplementing 1-valine and 1-isoleucine in low-protein corn and soybean meal all-vegetable diets for broilers. J. Appl. Poult. Res., 19: 373-379

Bregendahl K., J. L. Sell and D. R. Zimmerman (2002). Effect of low-protein diets on growth performance and body composition of broiler chicks. Poult. Sci., 81, 1156-1167.

Brosnan, J.T., E.P. Wijekoon, L. Warford-Woolgar, N.L. Trottier, M. E. Brosnan, J.A. Brunton and R.F.P. Bertolo (2009). Creatine synthesis is a major metabolic process in neonatal piglets and has important implications for amino acid metabolism and methyl balance. J. Nutr. 139:1292-1297.

Bunchasak C., U. Satoso, K. Tanaka, S. Ohtani and C. M. Collado (1997). The effect of supplementing methionine plus cystine to a low protein diet on the growth performance and fat accumulation of growing broiler chicks. Asian-Aust. J. of Anim. Sci., 10: 185-191.

Cheng, T. K., M. L. Hamre, and C. N. Coon. (1997). Responses of broilers to dietary protein levels and amino acid supplementation to low protein diets at various environmental temperatures. J. Appl. Poult. Res. 6:18-33

Corzo A., R. E., I. I. Loar and M.T. Kidd. (2009). Limitations of dietary isoleucine and valine in broiler chick diets. Poult. Sci., 88:1934-1938.

Dilger R.N., K. Bryant-Angeloni, R. L. Payne, A. Lemme, and C.M. Parsons (2013). Dietary guanidino acetic acid is an efficacious replacement for arginine for young chicks. Poult. Sci., $92: 171-177$.

Duncan, D.B. (1955). Multiple ranges and multiple F test. Biometrics, 11: 1-42.

Emmert, J. (2000). Efficiency of phase feeding in broilers. Proceeding, California Animal Nutrition Conference. Freesno California, USA.

Esser A. F. G., D. R. M. Gonçalves, A. Rorig, A. B. Cristo, R. Perini and J. I. M. Fernandes (2017). Effects of guanidionoacetic acid and arginine supplementation to vegetable diets fed to broiler chickens subjected to heat stress before slaughter. Braz. J. of Poult Sci., 19: 429-436.

Hai-ming Y., W. Wei, W. Zhi-yue, Y. Zhi, W. Yan, H. Bang-hong, H. Kai-hua, L. Hao (2015). Effects of early energy and protein restriction on growth performance, clinical blood parameters, carcass yield, and tibia parameters of broilers. J. of Integrative Agriculture.

Hidalgo, M.A., W.A. Dozier III, A.J. Davis and R.W. Gordon (2004). Live performance and meat yield responses to progressive concentrations of dietary energy at a constant metabolizable energy-to-crude protein ratio. J. Appl. Poult. Res. 13:319-327.

Jaroslav, H.; J. Zelenka; V. Machander; C. de la Cruz; M. Lestak and D. Hampel (2014). Effects of guanidine acetic acid supplementation to broiler diets with varying energy content. Acta Univ. Agric. Et Silvic. Mede. Brune. 62(3): 477-485.

Kamran Z., M. Sarwar, M. Nisa, M. A. Nadeem, S. Ahmad, T. Mushtaq, T. Ahmad and M. A. Shahzad (2008a). Effect of lowering dietary protein with constant energy to protein ratio on growth, body composition and nutrient utilization of broiler chicks. Asian-Aust. J. Anim. Sci., 21(11):1629-1634.

Kidd, M. T., B. J. Kerr, J. D. Firman, and S. D. Boling. (1996). Growth and carcass characteristics of broilers fed low-protein, threonine-supplemented diets. J. Appl. Poult. Res. 5: 180-190. 


\section{El-Faham et al.}

Kumar C.B., R.G. Gloridoss, K. Singh, T. M. Prabhu, Siddaramanna, B.N. Suresh and G.A. Manegar (2016). Performance of broiler chickens fed low protein, limiting amino acid supplemented diets formulated either on total or standardized ileal digestible amino acid basis (2016). Asian Aust.. J. Anim. Sci., 29:1616-1624.

Laudadio V, L. Passantino and A. Perillo, G. Lopresti, A. Passantino, R. U. Khan, and V. Tufarelli (2012). Productive perfor-mance and histological features of intestinal mucosa of broiler chickens fed different dietary protein levels. Poult Sci., 91:265-70

Lemme A., J. Ringel, H., S. Rostagno and M. S. Redshaw (2007a). Supplemental guanidino acetic acid improved feed conversion, weight gain, and breast meat yield in male and female broilers. pp 1-4 in Proc. XVI Eur. Symp. on Poultry Nutr., Strasbourg, France.

Lemme A., J. Ringel, A. Sterk and J. F. Young (2007b). Supplemental guanidino acetic acid affects energy metabolism of broilers. pp 339-342 in Proc. XVI Eur. Symp. on Poult. Nutr., Strasbourg, France.

Lemme A., R. Gobbi, A. Helmbrecht, J. D. Van Der Klis, J. Firman, J. Jankowski, and K. Kozlowski. (2010a). Use of guanidino acetic acid in all-vegetable diets for turkeys. 4th Turkey Science and Production Conference, 57-61.

Lemme A., C. Elwert, R. Gobbi, and M. Rademacher. (2011). Application of the guanidino acetic acid as creatine source in broilers fed diets with or without fish meal. 18th Symposium on Poultry Nutrition, $453-455$.

Law F.L., I. Zulkifli, A. F. Soleimani, J. B. Liang, and E. A. Awad (2018). The effects of low-protein diets and protease supplementation on broiler chickens in hot and humid tropical environment. Asian-Aust. J Anim Sci., 31:1291-1300.

Malheiros R. D., V. M. Moraes, A. Collin, G. P. Janssens, E. Decuypere and J. Buyse (2003). Dietary macronutrients, endocrine functioning and intermediary metabolism in broiler chickens: pair wise substitutions between protein, fat and carbohydrate. Nutr Res. 23:567-578.

Michiels J., L. Maertens, J. Buyse, A. Lemme, M. Rademacher, N. A. Dierick, and S. De Smet (2012). Supplementation of guanidinoacetic acid to broiler diets: Effects on performance, carcass characteristics, meat quality, and energy metabolism. Poult Sci $91: 402-412$.

Mousavi S. N., A. Afsar and H. Lotfollahian (2013). Effects of guanidino acetic acid supplementation to broiler diets with varying energy contents. J. Appl. Poult. Res. 22 :47-54.

Nawaz H., T. Mushtaq and M. Yaqoob M. (2006). Effect of varying levels of energy and protein on live performance and carcass characteristics of broiler chicks. J. of Poult. Sci., 43, 388-393.

NRC, (1994). Nutrient Requirements of Poultry. $9^{\text {th }}$ Revised edition. National Academy Press: Wasington, DC.

North M.D. (1981). Commercial Chicken Production. Annual. $2^{\text {nd }}$ Ed., AV., Publication Company. I.N.C., West Post Connecticut, USA.

Rezaei, M., Nassiri, M.H., Pour Reza J. and Kermanshahi, H. (2004). The effects of dietary protein and lysine levels on broiler performance, carcass characteristics and N excretion. Int. J. Poult. Sci., 3: 148152.

Ringel J, A. Lemme, M. S. Redshaw, K. Damme (2008b). The effects of supplemental guanidino acetic acid as a precursor of creatine in vegetable broiler diets on performance and carcass parameters. Poult Sci 87(Suppl 1):72.

Ringel J., A. Lemme and L. F. Araujo (2008a). The effect of supplemental guanidine acetic acid in Brazilian type broiler diets at summer conditions. Poultry Sci. 87(Suppl.1):154.

SAS (2001). SAS procedure guide version $6.12^{\text {th }}$ Ed. SAS Institute Inc., Cary, NC and UCA.

Sterling K.G., G.M. Pesti, and R.I. Bakalli (2003). Performance of Broiler Chicks Fed Various Levels of Dietary Lysine and Crude Protein. Poult. Sci., 82: 1939-1947.

Summers J.D., D. Spratt and J.L. Atkinson (1992). Broiler weight gain and carcass composition when fed diets varying in amino acid balance, dietary energy, and protein level. Poult. Sci., 71: 263-273. 
Waguespack A.M., S. Powell, T.D. Bidner, R.L. Payne and L.L. Southern (2009). Effect of incremental levels of L-lysine and determination of the limiting amino acids in low crude protein corn-soybean meal diets for broilers. Poultry Sci. 88:1216-1226

\section{تأثير إضافة مستويات مختلفة من جوانيدو استيك أسيد إلى علائق بدارى التسمين المنخفضة في البروتين على

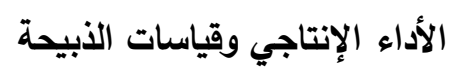

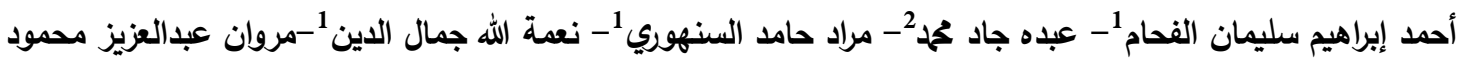

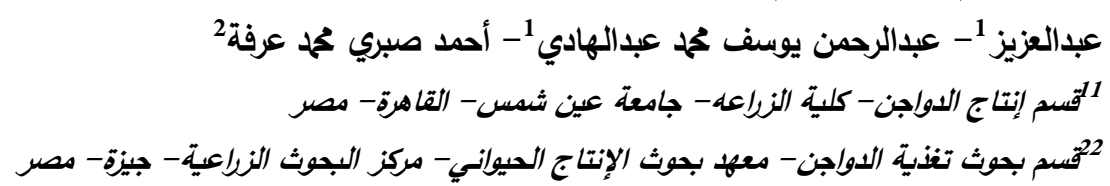

أجرى هذا البحث لدراسة تأثير إضافة مستويات مختلفةهن جوانيدو أستيك أسيد (GAA) إلى علائق بدارى التسمين تحتوى على على مستويات مختلفة من البروتين على الأداء الإنتاجي وصفات الذبيحة. إستخدم في هذا البحث 360 كتكوت عمر يوم من ذكور سلالة الهبرد حيث تم توزيعها عشوائياً في تصميم تجربة عاملية (2×3) على 6 معاملات غذائية كل معاملة 60 كتكوت تحتوي على 6 مكردات الإتئي كتكوت/ مكرر) كما يلي: (SD) عليقة قياسية: GAA \%0.06 + (SD) عليقة قياسية 0 -T2 GAA \%0.12 + (SD) عليقة قياسية

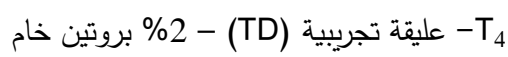
GAA \%0.06+ (TD) عليقة تجريبية GAA \%0.12 +(TD) عليقة تجريبية

الأداء الإنتاجي لبدارى التسمين (وزن الجسم الحي وزن الجسم المكتسب وكفاءة التحويل الغذائي ومعامل الأداء ومعامل الإنتاج وكفاءة تحويل البروتين وكفاءة تحويل الطاقة) تأثر معنوياً بمستوي إضافة GAA وكذلك مستوى بروتين العليقة خلال الفترة التجريبية (1-35 يوم) من العمر • لم يتأثر إستهلاك العلف بالمعاملات الغذائية المختلفة.

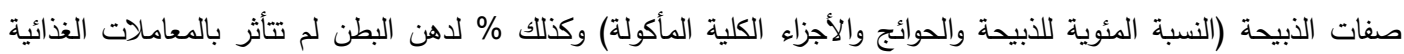

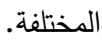
وقد خلصت الدراسة إلى إمكانية إضافة الجوانيدو أستيك أسيد لعلائق كتاكيت التسمين القياسية بمستوى 0.06\% أو للعلائق المنخفضة في البروتين (-2\%) بمستوى 0.12\% لتحقيق أفضل أداء إنتاجي بدون تأثيرات سيئة على صفات الذبيحة . 